\title{
АНАЛИЗ ОПЫТА РЕАЛИЗАЦИИ ПОДХОДОВ К УПРАВЛЕНИЮ ЧЕЛОВЕЧЕСКИМ КАПИТАЛОМ В СИСТЕМЕ РЕГИОНАЛЬНОЙ ЭКОНОМИКИ
}

\author{
(c) 2021 Мельников Павел Владимирович \\ соискатель Высшей инженерно-экономической школы \\ Санкт-Петербургский политехнический университет Петра Великого, Россия, Санкт-Петербург \\ E-mail:mel700@inbox.ru
}

В настоящее время вопросы повышения эффективности регионального развития приобрели особое значение, что связано с необходимостью снижения дифференциации социальноэкономического потенциала регионов как основы эффективного функционирования экономической системы Российской Федерации. Сглаживание территориальных диспропорций позволяет добиться однородности экономического пространства и преодоления разрыва в уровне и качестве жизни населения. Это способствует формированию на соответствующих территориях человеческого капитала необходимого качества, который выступает в качестве особого ресурса региональной экономики. Регионы имеют различные возможности в управлении человеческим капиталом, регионылидеры выделяют на решение вопросов социального развития значительно больше средств. Дифференциация при этом проявляется как на межрегиональном, так и на внутрирегиональном уровнях. Поэтому необходим поиск путей совершенствования рационального использования человеческого капитала региона как основы ресурсного обеспечения региональной экономики. В данной статье рассматривается опыт реализации подходов к управлению человеческим капиталом в системе региональной экономики, сделан вывод о том, что человеческий капитал становится главным активом экономической деятельности в стране. Наиболее успешные практики связаны с вовлечением в процесс управления человеческим капиталом всех заинтересованных сторон.

Ключевые слова: управление человеческим капиталом, региональная экономика, стратегия развития.

Трансформация российской хозяйственной системы связана не только с изменениями в структуре экономики, преодолением межрегиональной дифференциации, но и изменениями в человеческом капитале [1]. Управление человеческим капиталом в последние годы рассматривается как основа формирования долгосрочных факторов экономического роста, поэтому вопросам социальной политики уделяется значительное внимание федеральными властями. Достаточно только отметить, что на протяжении ряда лет в структуре расходов федерального бюджета заметно преобладают расходы социальной направленности. Так, доля расходов на социальную политику составило: в 2018 г.-28\%, в $2019-27 \%$, в $2020-26 \%$, прогнозное значение на 2021 г. - 24\%. Если к этим величинам добавить расходы на здравоохранение, образование, физическую культуру и спорт, охрану окружающей среды, то можно с уверенностью констатировать социальную ориентированность государства, связанную с формированием и поддержанием благоприятных условий жизнедеятельности населения как основы человеческого капитала.

Вопросы управления человеческим капиталом также рассматривались в ряде стратегических документов. Так, например, можно отметить Концепцию долгосрочного социальноэкономического развития РФ до 2020 года [2], согласно которой векторами развития человеческого капитала выступали повышение уровня конкурентоспособности трудовых ресурсов на основе приобретения новых компетенций, востребованных рынком труда, обеспечение эффективности занятости и улучшение социальной инфраструктуры в стране. В качестве ключевых задач в Концепции выделялись такие, как формирование благоприятной среды для осуществления трудовой деятельности и сокращения уровня теневой занятости; развитие профессионального образования, которое способно удовлетворить потребности рынков труда с учётом региональной специфики, вовлечение частных и государственных структур в развитие 
механизма использования трудовых ресурсов, включая применение принципа территориальной мобильности; оптимизация процессов привлечения иностранной рабочей силы при соблюдений гарантий гражданам РФ и другие.

Отдельным аспектам управления человеческим капиталом уделено внимание в Стратегии пространственного развития РФ до 2025 года, принятой в 2019 году. Это касается проблем развития малых и средних городов, сельских территорий, перспективы которых в данном документе увязаны с повышением экономической связности с агломерациями, обеспечением транспортной доступности и оптимизации территориальной доступности объектов социальной инфраструктуры [3]. При рассмотрении городских территорий указывается, что стратегии их развития должны учитывать, в частности, интегральный индекс качества человеческого капитала, а также статус поселения (в том числе отдельно выделены такие, как моногород, историческое поселение, наукоград). Сама Стратегия нацелена на преодоление пространственных диспропорций, характерных для российской социально-экономической системы. Отдельно при этом выделяются территории со значительным экономическим потенциалом и неблагоприятными демографическими показателями, управление которыми должно быть связано с созданием условий для привлечения населения как основы импульса их развития [3]. Реализация указанной Стратегии тесно связана с проблемами мобильности человеческого капитала и возможностями его перелива (перераспределения) между различными территориями. На территории Российской Федерации объемы человеческих ресурсов распределены крайне неравномерно. Приоритетным направлением мобильности населения являются рабочие места в крупных городах, которые, как правило, размещены в развитых регионах [4-6]. Отметим, что в перспективе изменение уровня доступного трудовых ресурсов приведет к росту мобильности с точки зрения смены региона приложения рабочей силы и повлияет на изменение сальдо миграции (как внешней, так и внутренней).

Изменению подходов к управлению человеческим капиталом способствует формирование цифровой экономики. Цифровизация предъявляет новые требования к человеческому капиталу, знаниям, умениям и навыкам, вызывает трансформацию структуры профессий [7,8].
Предприятия в условиях цифровой экономики содержательно меняют свою структуру, информационную среду функционирования, что порождает новые потребности в персонале [9]. Развитие инновационной деятельности возможно только с опорой на человеческий капитал с новыми качественными характеристиками [10,11]. В свою очередь, это означает, что создаются новые вызовы системе образования, которая должна соответствовать новым тенденциям [12]. Преобразования в части влияния социальноэкономических факторов на человеческий капитал требуют модернизации системы профессиональной подготовки и переподготовки кадров. Влияние личностных качеств работников и их способность к труду переходят на первый план, так от этого зависит профессиональная самореализация в условиях цифровизации экономики [13]. Это требует внимания со стороны органов федерального и регионального управления, учёта данного аспекта в разрабатываемых стратегиях и программах.

В целом основные проблемы человеческого капитала в значительной степени решаются на региональном уровне управления, что также подтверждается значительными объёмами расходов социального характера, осуществляемых за счёт консолидированных бюджетов субъектов РФ. Согласно данным рейтингового агентства РИА Рейтинг, во всех регионах в 2020 году наблюдался рост расходов консолидированных бюджетов регионов на социальную сферу (согласно методике агентства, социальная сфера региона трактуется широко и включает, наряду с аналогичными упомянутым выше направлениям расходов, также финансирование сферы культуры и некоторые другие). Если выстроить по мере убывания прирост данных расходы, то последовательность будет выглядеть следующим образом: на первом месте ожидаемо прирост расходов на здравоохранение (на 71,5\% в суммарных расходах консолидированных бюджетов всех субъектов), далее - на социальную политику - на 23,6\%, на физическую культуру и спорт - на 13,4\%, на образование - на 5,8\% по сравнению с 2019 годом. Расчёты, проведённые агентством, при этом показали очень высокий уровень дифференциации показателя объёма подушевых скорректированных социальных расходов в различных регионах. Так, в регионахлидерах этот показатель по первой десятке составил от 75 тыс.руб на человека (например, 
Ленинградская область, Московская область, Тюменская область) до 124,76 тыс. руб. на человека в Москве. А в регионах-аутсайдерах (десять регионов с наихудшими показателями) этот показатель составляет от 35 тыс.руб. на человека (Чукотский автономный округ и Камчатский край). Отмечается также, что все консолидированные региональные бюджеты являются социально ориентированными, так как общая доля социальных расходов в них превышает 50\% [14]. Выделение значительного объема финансовых ресурсов на поддержание и развитие социальной сферы актуализирует вопросы выбора эффективных моделей управления человеческим капиталом, которые позволяют использовать эти средства с максимальным результатом.

В социально-экономическом пространстве России можно выделить группы регионов, объединенных общей спецификой, где управление человеческим капиталом имеет схожие черты. Это, например, Арктические регионы (эта группа регионов включает полностью Мурманскую область, Ненецкий и Ямало-Ненецкий автономные округа, Чукотский АО, частично - Красноярский край, Архангельская область, Карелия и Якутия). Для этих регионов сформировано Агентство по развитию человеческого капитала в Арктике, которое уделяет внимание обеспечению человеческими ресурсами реализуемых инвестиционных проектов [15]. Как отмечается в источнике, эта организация ориентирована на подбор необходимых специалистов (в качестве приоритетных отраслей отмечаются такие, как горнодобывающая и нефтегазовая, судостроение, транспортное обслуживание, здравоохранение, топливо-энергетический комплекс; для арктических регионов Карелии потребности в человеческом капитале связаны с социальной сферой - образования, здравоохранения, культуры; Красноярский край испытывает потребности в специалистах добывающей промышленности для крупных инвестпроектов), совершенствование системы образования, сохранение условий жизнедеятельности коренных народов Севера. Основная задача Агентства координация усилий различных заинтересованных сторон (в частности, вузов и предприятий региона), нацеленная на формирование человеческого капитала с необходимыми характеристиками, использование которого в арктических регионах будет способствовать достижению их устойчивого социально-экономического разви- тия. Ключевыми проблемами данной территории выступают проблемы закрепления кадров, сохранения традиционных видов занятий коренных народов, а также стимулирования расширения бизнеса с созданием новых рабочих мест для местных жителей. На наш взгляд, наличие таких специализированных организационных структур позволяет комплексно решать проблемы управления человеческим капиталом на межрегиональном уровне, кроме того, учитывать специфику территорий, которые не полностью относятся к одному из субъектов РФ.

Управление человеческим капиталом в регионах должно строиться на основе стратегических документов социально-экономического развития как национального, так и регионального уровней (в том числе национальных целей развития РФ), поскольку они определяют перспективные требования к носителям человеческого капитала и позволяют выстраивать соответствующую систему образования и социальную инфраструктуру [16].

В регионах применяются различные подходы к определению приоритетов, выбора вариантов финансирования различных аспектов, связанных с человеческим капиталом. Следует обратить внимание на положительный опыт вовлечения заинтересованных сторон в процессы управления. Некоторые регионы применяют организационные решения, позволяющие использовать возможности государственных и негосударственных структур. Например, в Москве осуществляется совместная деятельность Департамента труда и занятости, Некоммерческой организации «Ассоциация консультантов по подбору персонала» и открытого независимого профессионального объединения «Национальная конфедерация «Развитие человеческого капитала» на базе города Москвы. НК «Развитие человеческого капитала» занимается проведением мероприятий по обучению кадров, созданием стандартов профессионального качества на уровне страны и принимает участие в исполнении государственных программ. Эта конфедерация также взаимодействует с Центром занятости молодежи г. Москвы, а также с ведущими вузами, в частности, с экономическим факультетом МГУ (реализовывает программу профессиональной переподготовки в области управления персоналом) [17]. На наш взгляд, такое взаимодействие позволяет более полно выделить и учесть проблематику человеческого капитала. 
В других регионах также имеется определённый опыт деятельности особых координирующих организаций. Так, при поддержке Комитетов по труду и занятости Санкт-Петербурга и Ленинградской области создана некоммерческая организация «Агентство по развитию человеческого капитала в Северо-Западном федеральном округе», в состав учредителей которой входят объединения представителей бизнеса (Союзы промышленников и предпринимателей двух регионов). Структура выполняет функции регионального методического центра по развитию квалификаций, занимается вопросами координации деятельности в области труда и занятости [18]. В то же время, представляется, что объединение задач Санкт-Петербурга и Ленинградской области не вполне эффективно, так как для Ленинградской области характерны специфические проблемы в сфере труда и занятости, в особенности в муниципальных образованиях с неблагоприятной социально-экономической ситуацией, и их необходимо решать с учётом соответствующей специфики. Это же касается и особенностей управления системой образования в этих двух регионах. Также надо отметить, что в целом идея независимой оценки квали- фикации, на наш взгляд, формирует недоверие к системе государственной аттестации выпускников, и вероятно, стоило бы совершенствовать именно эту процедуру. Кроме того, соответствие качества подготовки носителей человеческого капитала требованиям рынка труда могла бы обеспечить точная имплементация требований профессиональных стандартов в образовательные (как это и происходит в ряде стран). Тем не менее, потенциал Агентства мог бы быть использован при решении комплексных вопросов развития территорий на основе совершенствования использования человеческого капитала.

Таким образом, человеческий капитал все в большей мере становится главной движущей силой экономической деятельности в стране. Реализация подходов к управлению человеческим капиталом должна учитывать уровень поддержки федерального центра и национальные приоритеты; региональные различия; возможности вовлечения представителей бизнеса и общественных организаций в процессы разработки и принятия решений. Это требует поиска путей координации взаимодействий различных заинтересованных сторон в регионе с учётом особенностей муниципальных образований.

\section{Библиографический список}

1. Харламов А.В., Харламова Т. Л. Трансформация российской хозяйственной системы: теоретические и практические аспекты //Известия Юго-Западного государственного университета. Серия: Экономика. Социология. Менеджмент. - 2019.- Т. 9.- № . 4.- С. 8-16.

2. Распоряжение. Правительства РФ от 17.11.2008 N 1662-р (ред. от 28.09.2018) «О Концепции долгосрочного социально-экономического развития Российской Федерации на период до 2020 года.»

3. Стратегия. пространственного развития РФ до 2025 г. URL: https://www.economy.gov.ru/material/file/a3d075 aa813dc01f981d9e7fcb97265f/130219_207-p.pdf.

4. Коновалова Т.В., КоломеецН.В. Основные пути и методы повышения городской мобильности населения // Наука. Техника. Технологии (политехнический вестник). Общество с ограниченной ответственностью Издательский Дом-Юг, 2017. № 2. Р. 185-189.

5. Фаттахов Р.В., Низамуттдинов М.М., Орешников В.В. Анализ пространственной мобильности населения регионов России: тенденции и механизмы регулирования // Экономика в промышленности. 2017. Vol. 10, № 2. P. 162-171.

6. Сагинов Ю.Л., Завьялов Д. В. Направления развития моделей мобильности в большом городе // Экономика, предпринимательство и право. Общество с ограниченной ответственностью Издательство «Креативная экономика», 2020. Vol. 10, № 2 .

7. Konnikov E. et al. Analysis and Prospects of the Digital Economy in Russia // IOP Conference Series: Materials Science and Engineering. 2020. Vol. 940, № 1.

8. Zaborovskaia. O., Nadezhina O., Avduevskaya E. The Impact of Digitalization on the Formation of Human Capital at the Regional Level //Journal of Open Innovation: Technology, Market, and Complexity. 2020. T. 6. № 4. C. 1-24.

9. Rodionov D. et al. Modeling Changes in the Enterprise Information Capital in the Digital Economy // J. Open Innov. Technol. Mark. Complex. Multidisciplinary Digital Publishing Institute, 2021. Vol. 7, № 3. P. 166.

10. Родионов Д.Г., Афанасьева Н. В. Стратегия повышения эффективности функционирования инновационного предприятия. Российский экономический интернет-журнал. 2018. № 4. С. 94. 
11. Zaytsev A. et al. Comparative analysis of results of using assessment methods for intellectual capital // IOP Conf. Ser. Mater. Sci. Eng. 2020. Vol. 940, № 1.

12. Харламова Т.Л.Инновационная система образования и развитие человеческого капитала //Российский экономический интернет-журнал. - 2019. - № . 1.- С. 74-74.

13. Григорьев С.Г., Лукин В.В., ЛукинД.В. Развитие человеческого капитала в условиях цифровизации // E-Management. 2018. Vol. 1, № 2.

14. РИА. Рейтинг URL: https://riarating.ru/.

15. Развитие. человеческого капитала в Арктике: какие меры поддержки ждут регионы URL: https://tass.ru/ ekonomika/7793593.

16. Заборовская О.В., Рымарчук Д. С. Задачи управления человеческими ресурсами ленинградской области в контексте национальных целей развития Российской Федерации // Журнал правовых и экономических исследований. 2020. № 4. Р. 197-204.

17. Национальная. конфедерация «Развитие человеческого капитала». URL: http:/hrdevelopment.ru/about_ confederation/.

18. Национальное. агентство развития квалификаций. URL: https://nark.ru/activity/regions/rmc/g-sanktpeterburg-i-leningradskaya-obl.php. 